\title{
Retinal dystrophy with inner retinal dysfunction and ganglion cell anomalies
}

INSERM

\section{Source}

INSERM. (1999). Orphanet: an online rare disease and orphan drug data base. Retinal dystrophy with inner retinal dysfunction and ganglion cell anomalies. ORPHA:397758

Retinal dystrophy with inner retinal dysfunction and gang lion cell anomalies is a rare, genetic, retinal dystrophy disorder characterized by decreased central retinal sensitivity associated with hyper-reflectivity of gang lion cells and nerve fiber layer with loss of optic nerve fibers manifesting with fotophobia, optic disc pallor and progressive loss of central vision with preservation of peripheral visual field. 